\title{
ROZWÓJ RYNKU NEWCONNECT W ŚWIETLE ZALOŻEŃ JEGO ORGANIZATORA
}

\section{WSTĘP}

Głównym motorem napędowym polskiej gospodarki sa mikro-, małe i średnie przedsiębiorstwa (MŚP). Wskazana grupa podmiotów odpowiadała w 2012 r. za wygenerowanie 48,5\% wartości dodanej brutto PKB przez przedsiębiorstwa w Polsce, przy udziale dużych przedsiębiorstw wynoszącym $24,5 \%$, pozostałych podmiotów $-15,6 \%$ oraz ceł i podatków $-11,4 \%$. Ponadto na koniec 2013 r. mikro-, małe i średnie przedsiębiorstwa stanowiły aż 99,8\% wszystkich podmiotów niefinansowych prowadzących działalność w Polsce (w grupie liczącej 1,77 mln podmiotów), jednocześnie należy wskazać, że zatrudniały one $69 \%$ z 8,9 mln osób pracujących. W 2007 r. Giełda Papierów Wartościowych w Warszawie SA utworzyła z myślą o małych i średnich przedsiębiorstwach rynek akcji w formule alternatywnego systemu obrotu. Rynek ten nazwany został rynkiem NewConnect i miał w swoim zamyśle przyczynić się do ułatwienia pozyskania finansowania przez małe i średnie innowacyjne przedsiębiorstwa.

Biorąc pod uwagę istotność mikro-, małych i średnich przedsiębiorstw dla polskiej gospodarki, celem niniejszego artykułu jest weryfikacja wybranych początkowych założeń organizatora rynku NewConnect, tj. założeń w zakresie rozmiaru debiutujących emitentów i rodzaju prowadzonej przez nich działalności.

Osiąnięcie przedstawionego celu zakłada weryfikację hipotezy głównej opracowania, zgodnie z która: rynek NewConnect jest rynkiem zdominowanym przez mikro-, małe i średnie przedsiębiorstwa. Ponadto w niniejszym artykule uwzględniono następującą hipotezę cząstkowa, która pozwala na pełniejszą weryfikację celu głównego: rynek NewConnect jest rynkiem nie tylko dla spółek kwalifikowanych do branż innowacyjnych.

Artykuł składa się ze wstępu, dwóch części zasadniczych oraz podsumowania. We wstępie przedstawiony został cel, towarzyszący całemu opracowaniu, oraz hipoteza główna i cząstkowa. W pierwszej z części zasadniczych zaprezentowano podstawy teorii wpływu rozwoju rynku finansowego na wzrost gospodarczy, przesłanki utworzenia rynku NewConnect oraz aktualne kryteria wprowadzenia do obrotu. W drugiej z części zasadniczych zawarto wyniki badań nad wielkością emitentów, którzy zdecydowali się wprowadzić 
swoje akcje na rynek NewConnect, a także nad ich charakterystyką. W podsumowaniu zaprezentowano ostateczną weryfikację hipotez towarzyszacych badaniu, a także przedstawiono ogólne wnioski płynące z badania, wskazując jednocześnie obszary wymagające dalszej dogłębnej analizy.

\section{WYBRANE BADANIA W ZAKRESIE TEORII WPLYWU ROZWOJU RYNKU FINANSOWEGO NA WZROST GOSPODARCZY}

Jedną z głównych postaci, która podniosła kwestię wpływu rozwoju rynku finansowego na wzrost gospodarczy, był Joseph Schumpeter. Stał na stanowisku, że rynki finansowe w istotny sposób przyczyniają się rozwoju gospodarczego. Uważał, że najważniejszą funkcją rynków finansowych jest łączenie ze sobą strony popytowej na kapitał finansowy, utożsamianej z przedsiębiorcami, ze strona podażowa, czyli z pośrednikami finansowymi.

Bezpośrednio do koncepcji stworzonej przez Josepha Schumpetera odniósł się Ross Levine. Według Levine’a do głównych czynników przyczyniających się do powstawania rynków finansowych wraz z ich infrastrukturą instytucjonalna sa koszty informacyjne oraz koszty transakcyjne. Rynki te ograniczaja koszty informacyjne i transakcyjne dzięki usprawnieniu alokacji kapitału $\mathrm{w}$ czasie i przestrzeni, przy niepewnym otoczeniu.

W ocenie R. Levine'a rynki finansowe pełnią szereg istotnych funkcji, do których zaliczył on:

- wspomaganie handlu, a także zabezpieczanie, dywersyfikację oraz koncentrację ryzyka,

- ułatwienie i usprawnienie alokacji posiadanych zasobów,

- wzmocnienie kontroli i monitoring menedżerów oraz ładu korporacyjnego,

- dokonywanie mobilizacji oszczędności,

- ułatwienie i usprawnienie wymiany towarów, usług i kontraktów.

R. Levine, odwołując się do endogenicznych modeli wzrostu gospodarczego, wskazał, że każda z wyżej wymienionych funkcji może wpłynać na wzrost gospodarczy na dwa różne sposoby, tj. poprzez kanał akumulacji kapitału lub kanał innowacji. Endogeniczne modele wzrostu gospodarczego powstały w wyniku krytyki modelu Solowa, dlatego charakteryzuje je odejście od założenia o stałych efektach skali produkcji w gospodarce i próba włączenia do modeli stopy oszczędności (inwestycji) oraz postępu technicznego przy jednoczesnym założeniu o ograniczoności zasobów naturalnych (m.in. modele Romera, Lucasa, Aghiona i Howitta). Zgodnie z założeniami zaliczanego do prostych modeli wzrostu gospodarczego modelu $A K$ wysoki poziom oszczędności w gospodarce pozwala na sfinansowanie wyższej stopy postępu technicznego i tym samym osiagnięcie wzrostu gospodarczego. Zgodnie z tym założeniem rynki finansowe, przyczyniając się do modyfikacji stopy oszczędności lub ich realokacji, mogą wpływać na wzrost gospodarczy. Natomiast schumpeteriański model wzrostu przy ograniczoności zasobów naturalnych zakłada, że dany produkt jest sprzedawany dopóty, dopóki nie pojawi się jego bardziej zaawansowany technologicznie odpowiednik. We wskazanym modelu wzrost gospodarczy nie 
jest generowany przez akumulację kapitału, lecz dzięki wprowadzaniu nowych innowacji. W omawianym ujęciu rynki finansowe oddziałuja na wzrost przez finansowanie nowych rozwiązań, modyfikując współczynnik produktywności, będący jednym z elementów wpływających na ogólny poziom produkcji - i przekładając się bezpośrednio na generowanie wzrostu gospodarczego. Przedstawione ujęcia zostały bliżej zaprezentowane na schemacie 1.

\section{Schemat 1}

Teoretyczny związek między finansami a wzrostem

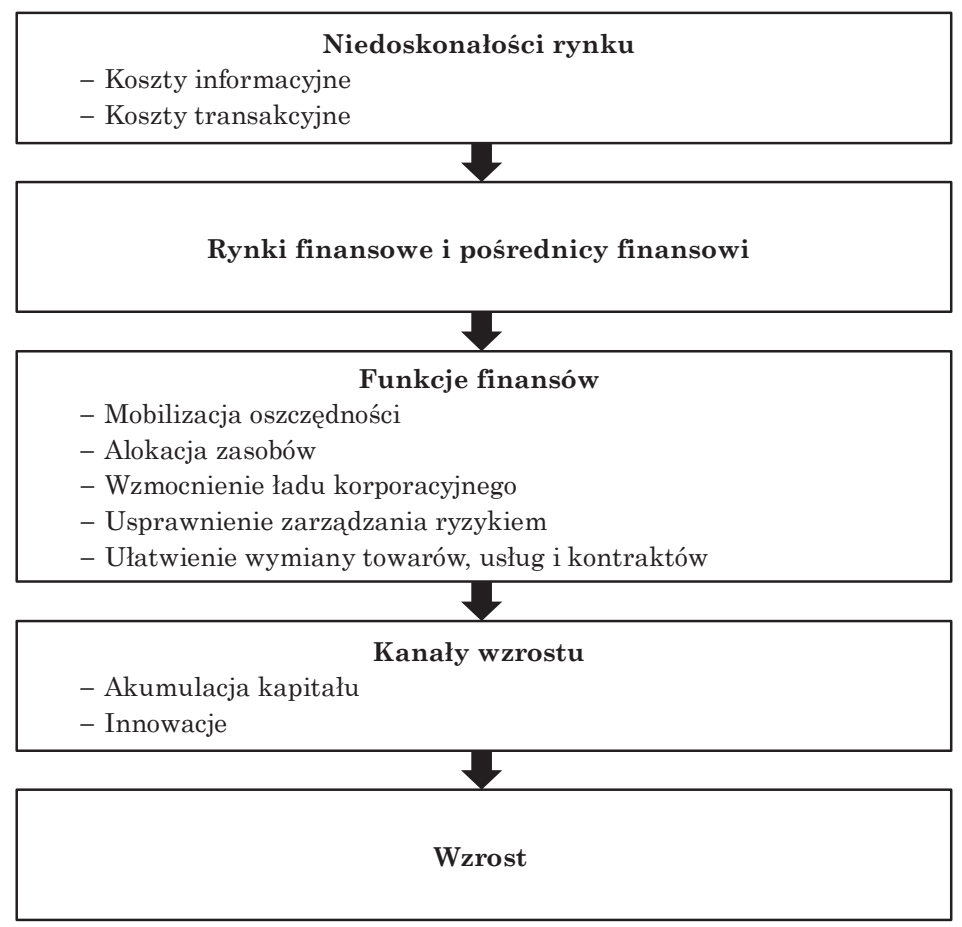

Źródło: opracowanie własne na podstawie R. Levine, op. cit., s. 691.

Kwestię wpływu rozwoju rynku finansowego na wzrost gospodarczy poruszyli także Robert King oraz Ross Levine. Przeanalizowali oni zależność pomiędzy poziomem realnego $\mathrm{PKB}$ per capita i rozmiarami pośrednictwa finansowego, które utożsamiali z relacją płynnych zobowiązań sektora finansowego do PKB. Wskazani badacze poddali analizie zależność pomiędzy wskaźnikami rozwoju finansowego i długookresowymi stopami wzrostu gospodarczego per capita, wzrostem produktywności oraz akumulacją kapitału. W każdym z analizowanych przypadków wskaźniki korelacji były statystycznie istotne ${ }^{1}$.

1 R. G. King, R. Levine, Finance and growth. Schumpeter might be right, „The Quarterly Journal of Economics" 108(3), 1993, s. 717-737. 
Badania w omawianym zakresie przeprowadzili również Wiesław Dębski oraz Iwona Bujnowicz. W swoim opracowaniu przeanalizowali oni występowanie współzależności zachodzących między rozwojem rynku finansowego a wzrostem gospodarczym w Polsce ${ }^{2}$. Autorzy badania mierzyli rozwój rynku finansowego jako sumę kapitalizacji giełdy papierów wartościowych w Warszawie, aktywów netto zakładów ubezpieczeń na życie, funduszy emerytalnych i inwestycyjnych oraz akcji kredytowej banków komercyjnych. Uzyskane wyniki badań pozwoliły im na wyciagnnięcie następujących wniosków:

- wzrost odsetka kapitalizacji giełdy papierów wartościowych w Warszawie przekłada się na wzrost PKB Polsce,

- wzrost aktywów netto sektora finansowego powoduje wzrost PKB w Polsce,

- wzrost odsetek emisji akcji lub nakładów inwestycyjnych w gospodarce przekłada się na wzrost kapitalizacji giełdowej ${ }^{3}$.

Badacze ci wykazali także, że występuje istotne połączenie sfery realnej gospodarki ze sfera finansowa, wskazali bowiem na zidentyfikowany proces, w którym realizacji inwestycji towarzyszy wchłonięcie aktywów finansowych i transformacja ich w aktywa rzeczowe ${ }^{4}$.

\section{IDEA POWSTANIA RYNKU NEWCONNECT}

Utworzony w 2007 r. rynek NewConnect wpisał się w trwający w tym czasie europejski trend tworzenia alternatywnych systemów obrotu. Warto wskazać, że zanim mieliśmy do czynienia z rynkiem NewConnect, podjęto próbę utworzenia podobnego rynku dla przedsiębiorstw niespełniających kryteriów dopuszczenia do obrotu na rynku regulowanym - mowa tutaj o uruchomionym 12 lutego 1996 r. rynku CeTO, który funkcjonował pod postacia rynku pozagiełdowego i miał być miejscem dla małych i średnich przedsiębiorstw oraz spółek pochodzących z Programu Powszechnej Prywatyzacji. Rynek ten nie wzbudził jednak nadmiernego zainteresowania ani ze strony emitentów, ani inwestorów, co ostatecznie doprowadziło do jego marginalizacji i reorganizacji polegającej na ukierunkowaniu na obsługę notowań papierów dłużnych ${ }^{5}$.

Pierwsze zarysy planu związanego z utworzeniem rynku akcji dla małych i średnich przedsiębiorstw pojawiły się kwietniu 2004 r. w opublikowanej przez Ministerstwo Finansów strategii rozwoju dla rynku kapitałowego w Polsce „Agenda Warsaw City 2010”. Strategia ta powstała we współpracy

${ }^{2}$ W. Dębski, I. Bujnowicz, Model wspótzależności rozwoju systemu finansowego i wzrostu gospodarczego w Polsce, Studia i Prace Wydziału Nauk Ekonomicznych i Zarządzania nr 9, WN US, Szczecin 2008, s. 12.

${ }^{3}$ Ibidem, s. 13-14.

${ }^{4}$ Ibidem, s. 15.

${ }^{5}$ D. Zawadka, Publiczny rynek kapitatu wysokiego ryzyka, CMT, Poznań 2013, s. 36.

${ }^{6}$ Agenda City Warsaw, Strategia rozwoju rynku kapitałowego „Agenda City Warsaw 2010”, Ministerstwo Finansów, Warszawa 2004. 
Ministerstwa Finansów z ówczesną Komisją Papierów Wartościowych i Giełd (obecnie Komisja Nadzoru Finansowego), Giełdą Papierów Wartościowych, Narodowym Bankiem Polskim oraz Krajowym Depozytem Papierów Wartościowych. Jednym z głównym celów wymienionej strategii było utworzenie w Polsce dużego, płynnego oraz bezpiecznego rynku kapitałowego wspierającego rozwój małych i średnich przedsiębiorstw.

Na schemacie nr 2 przedstawiony został moment utworzenia rynku NewConnect wobec trwającego wówczas trendu tworzenia alternatywnych systemów obrotu w Europie.

\section{Schemat 2}

Utworzenie rynku NewConnect na tle europejskiego trendu tworzenia ASO

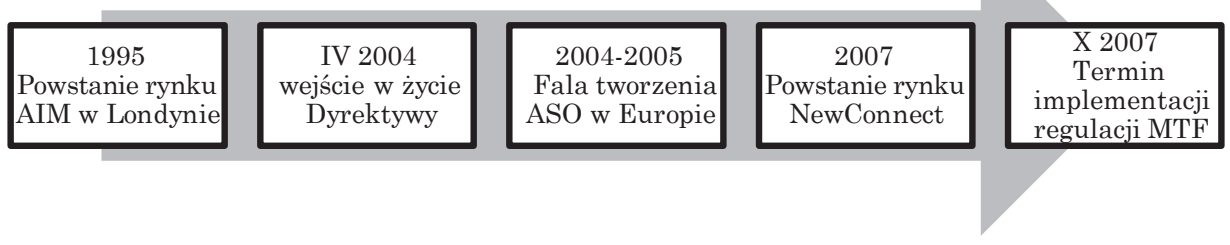

Źródło: D. Zawadka, Publiczny rynek kapitatu wysokiego ryzyka, CMT, Poznań 2013, s. 36.

W kwietniu 2004 r. Parlament Europejski uregulował tworzenie i funkcjonowanie alternatywnych systemów obrotu w krajach członkowskich w ramach przepisów dyrektywy MiFID (Markets in Financial Instruments Directive) ${ }^{7}$. Dyrektywa MiFID już we wstępie wskazuje na konieczność ustanowienia odpowiednich ram regulacyjnych dla usługi polegającej na prowadzeniu wielostronnych platform obrotu MTF (ang. multilateral trading facility) ${ }^{8}$. Komisja pojęcie platformy MTF definiuje jako: „wielostronny system, obsługiwany przez przedsiębiorstwo inwestycyjne lub podmiot gospodarczy, który kojarzy transakcje strony trzeciej w dziedzinie kupna i sprzedaży instrumentów finansowych - w systemie i zgodnie z regułami innymi niż uznaniowe - w sposób skutkujący zawarciem kontraktu zgodnie z przepisami tytułu II [dyrektywy MiFID - dop. P.Z.]"'.

W dalszej części omawianej dyrektywy na organizatorów platform obrotu nałożono szereg obowiązków, do których wliczają się:

${ }^{7}$ Dyrektywa 2004/39/WE Parlamentu Europejskiego i Rady z 21 kwietnia 2004 r. w sprawie rynków instrumentów finansowych zmieniająca dyrektywę Rady 85/611/EWG i 93/6/EWG i dyrektywę 2000/12/WE Parlamentu Europejskiego i Rady oraz uchylająca dyrektywę Rady 93/22/EWG (Dz. Urz. L 145 z 30 kwietnia 2004 r.).

8 Ibidem, s. 3.

${ }^{9}$ Ibidem, s. 17. 
- ustanowienie przejrzystych, nieuznaniowych reguł i procedur uczciwego oraz prawidłowego obrotu, a także ustalenie obiektywnych kryteriów skutecznego realizowania zleceń,

- ustanowienie przejrzystych reguł dotyczących kryteriów wprowadzenia do obrotu instrumentów finansowych,

- zapewnienie, że organizatorzy platform posiadają dostęp do odpowiednich, informacji umożliwiających użytkownikom platform formułowanie opinii inwestycyjnych, biorąc jednocześnie pod uwagę zarówno charakter użytkowników, jak i rodzaje instrumentów finansowych wprowadzanych do obrotu ${ }^{10}$.

Powyższe zapisy dyrektywy MiFID nakładaja tym samym na organizatorów platform MTF konieczność ustanowienia odpowiednich regulacji dla prowadzonych systemów, warunków obrotu i zawierania transakcji instrumentami finansowymi, a także konieczność ustalenia kryteriów wprowadzenia instrumentów do obrotu, jak i określenie zakresu ujawnianych przy tym informacji. Jednocześnie dyrektywa MiFID nie wskazuje enumeratywnie, jakie regulacje powinny obowiązywać $\mathrm{w}$ danym systemie, pozostawiając tym samym szeroką swobodę ich organizatorom. W 2018 r. postanowienia dyrektywy MiFID zostaną zastapione przez dyrektywę MiFID 2, która nie wprowadza istotnych zmian w zakresie funkcjonowania platform MTF.

Pierwszym i najbardziej rozpoznawalnym rynkiem akcji w Europie funkcjonującym $\mathrm{w}$ formule alternatywnego systemu obrotu jest londyński rynek AIM. Rynek ten powstał w 1995 r., a od 2004 funkcjonuje jako MTF, którego organizatorem jest London Stock Exchange. Prawdziwy wysyp tych rynków nastapił w 2005 r., kiedy to Euronext Amsterdam N.V. uruchomił rynek NYSE Alternext, Deutsche Borse wystartowało z Entry Standard, a w Luksemburgu utworzono rynek Euro MTF. W Polsce alternatywny system obrotu rozpoczał swoje funkcjonowanie 31 sierpnia 2007 r. pod postacią rynku NewConnect, a jego twórcą była Giełda Papierów Wartościowych w Warszawie SA. W zamyśle organizatora NewConnect rynek ten miał służyć małym i średnim przedsiębiorstwom o wysokim potencjalne rozwoju w pozyskiwaniu niezbędnego finansowania dla swojej działalności. Jednocześnie organizator wskazywał, że potencjał ten miał być wynikiem wykorzystania przez przedsiębiorstwa innowacyjności produktowej, usługowej lub procesów biznesowych ${ }^{11}$.

Tworzac rynek NewConnect, organizator oparł go na kilku założeniach:

- spółki będą pozyskiwały kapitał rzędu od kilkuset tysięcy do kilkudziesięciu milionów złotych,

- spółki będą reprezentowały sektory innowacyjne, oparte przede wszystkim na aktywach niematerialnych (np. IT, media elektroniczne, telekomunikacja, biotechnologie, ochrona środowiska, energia alternatywna, nowoczesne usługi),

- spółki o dużej dynamice wzrostu,

- spółki z sektora małych i średnich przedsiębiorstw,

- tańsze pozyskanie kapitału względem rynku regulowanego,

- miejsce notowań przed przenosinami na rynek regulowany ${ }^{12}$.

${ }^{10}$ Ibidem, s. 28.

${ }^{11}$ D. Zawadka, op. cit., s. 36.

12 Regulamin ASO (2016), Regulamin Alternatywnego Systemu Obrotu wraz z załącznikami w brzmieniu przyjętym uchwałą nr 147/2007 Zarządu Giełdy z 1 marca 2007 r., ze zm., s. 5-7. 
Odnosząc teorię wpływu rozwoju rynku finansowego na wzrost gospodarczy do rynku NewConnect i rozwoju gospodarczego w Polsce, należy wskazać, że jego utworzenie było dobrym posunięciem. Stworzenie nowego źródła finansowania dla dominującej grupy przedsiębiorstw w Polsce miało w istocie przyczynić się do ich szybszego rozwoju, a w efekcie również do szybszego wzrostu gospodarczego Polski. Ponadto rynek ten usprawnił proces alokacji i mobilizacji oszczędności przez inwestorów charakteryzujących się zwiększona skłonnością do ryzyka (m.in. fundusze venture capital oraz wybrani inwestorzy indywidualni), wzmocnił ład korporacyjny w najliczniejszej grupie przedsiębiorstw w Polsce, a także usprawnił proces zarządzania ryzykiem poprzez udział nowych grup inwestorów w danych przedsięwzięciach. Jednocześnie jednym z założeń organizatora rynku NewConnect, przy tworzeniu wspomnianego rynku, miało być utworzenie platformy pozyskania finansowania dla innowacyjnych przedsiębiorstw opierających swoją działalność w głównej mierze na wartościach niematerialnych. Tym samym rynek NewConnect mógł oddziaływać na wzrost gospodarczy zarówno poprzez kanał akumulacji kapitału (łączenie przedsiębiorstw i inwestorów), jak i kanał finansowania innowacji.

\section{KRYTERIA WPROWADZENIA DO OBROTU NA RYNKU NEWCONNECT}

Podmioty zamierzające wprowadzić swoje akcje do obrotu na rynku NewConnect muszą sprostać szeregowi kryteriów wprowadzeniowych, które zostały przedstawione przez organizatora rynku w Regulaminie ASO. Do kryteriów tych zaliczają się:

- sporządzenie i udostępnienie do publicznej wiadomości prospektu emisyjnego lub memorandum informacyjnego, a w przypadku braku jednego $\mathrm{z}$ wskazanych przedstawienie dokumentu informacyjnego w rozumieniu załącznika nr 1 do Regulaminu ASO wraz z oświadczeniem Autoryzowanego Doradcy,

- brak ograniczenia zbywalności akcji,

- brak toczącego się postępowania upadłościowego lub likwidacyjnego,

- wartość nominalna akcji nie mniejsza niż 0,10 zł (co odnosi się także do praw do akcji oraz praw poboru),

- odpowiednie rozproszenie akcji, rozumiane jako stan, w którym co najmniej 15\% akcji objętych wnioskiem o wprowadzenie jest w posiadaniu co najmniej 10 akcjonariuszy, z których żaden nie posiada więcej niż 5\% ogólnej liczby głosów na walnym zgromadzeniu i nie jest podmiotem powiązanym z emitentem akcji (stosowane także do praw do akcji),

- minimalna wartość kapitałów własnych na poziomie 500000 zł (organizator ASO może odstapić od tego wymogu w sytuacji, gdy sąd nie zarejestrował jeszcze podwyższenia kapitału zakładowego, po którym to wskazana wysokość zostanie osiąnięta), 
- przedstawienie w dokumencie informacyjnym sprawozdania finansowego lub skonsolidowanego sprawozdania finansowego za ostatni rok obrotowy wraz z opinią i raportem sporządzonym przez podmiot uprawniony do badania sprawozdań finansowych ${ }^{13}$.

Rodzaj dokumentu, który musi zostać sporządzony na potrzeby wprowadzenia akcji na rynek NewConnect, zależy co do zasady od dwóch czynników - rodzaju oferty oraz od zakładanej wartości wpływów z emisji. W przypadku przeprowadzania oferty publicznej, a więc oferty akcji skierowanej do co najmniej 150 osób lub nieoznaczonego adresata ${ }^{14}$, wymagane jest sporządzenie prospektu emisyjnego ${ }^{15}$, który podlega zatwierdzeniu przez Komisję Nadzoru Finansowego. Istnieje jednak szereg odstępstw od tego wymogu, przy czym z punktu widzenia małych i średnich przedsiębiorstw kluczowym wydaje się brak konieczności sporządzania prospektu w związku z przeprowadzaniem oferty publicznej, jeżeli szacowane wpływy brutto z jej tytułu nie przekraczają równowartości 2500000 euro $^{16}$. W takim przypadku emitenci mają możliwość sporządzenia memorandum informacyjnego, które nie podlega zatwierdzeniu przez Komisję Nadzoru Finansowego, a konieczne jest jedynie poinformowanie Komisji o zamiarze przeprowadzenia stosownej oferty zgodnie ze wspomnianym dokumentem ${ }^{17}$. Przyjmuje się, że przeprowadzenie oferty publicznej i wprowadzenie akcji do obrotu na rynku NewConnect na podstawie prospektu emisyjnego może trwać od 6 do 8 miesięcy ${ }^{18}$, natomiast w przypadku sporządzania memorandum informacyjnego proces ten przebiega szybciej.

Jeżeli emitenci zamierzają pozyskać kapitał o mniejszej wartości lub w szybszy sposób możliwe jest przeprowadzenie oferty w trybie prywatnym. Z ofertą tą utożsamiamy przede wszystkim maksymalną liczbę inwestorów, do których może być ona skierowana, w tym przypadku jest to nie więcej niż 149 oznaczonych adresatów ${ }^{19}$. W takim przypadku tworzony jest dokument ofertowy, którego zakres został uregulowany w załączniku nr 5 do Regulaminu $\mathrm{ASO}^{20}$. Dokument ten nie jest zatwierdzany przez żaden organ nadzoru, a sam fakt przeprowadzenia oferty prywatnej nie podlega zgłoszeniu. Po przeprowadzeniu oferty prywatnej, a jeszcze przed debiutem

\footnotetext{
${ }^{13}$ Regulamin Alternatywnego Systemu Obrotu wraz z załącznikami w brzmieniu przyjętym uchwałą nr 147/2007 Zarządu Giełdy z dnia 1 marca 2007 r., ze zm., s. 5-7 (dalej jako: Regulamin ASO).

14 Art. 3 ust. 1 ustawy o ofercie publicznej i warunkach wprowadzenia instrumentów finansowych do zorganizowanego systemu obrotu oraz o spółkach publicznych z 29 lipca 2005 r., Dz. U. 2005, Nr 184, poz. 1539 ze zm.

15 Ibidem, art. 7. ust. 1.

16 Ibidem, art. 7 ust. 9.

17 Ibidem, art. 41 ust. 2.

18 B. Mikołajczyk, A. Kurczewska, Rynek NewConnect $w$ Polsce na tle rynków alternatywnych $w$ Europie, „Finansowy Kwartalnik Internetowy „e-Finanse” 6, 2010, nr 3, s. 68.

${ }_{19}$ P. Zygmanowski, Finansowanie działalności przedsiębiorstw z wykorzystaniem IPO na polskim rynku kapitałowym, Studia i Prace Kolegium Zarządzania i Finansów SGH, Zeszyt Naukowy nr 140, Warszawa 2014, s. 131.

${ }^{20}$ Załącznik nr 5 do Regulaminu ASO, s. 5-7.
} 
na rynku NewConnect, emitenci zobowiązani są sporządzić dodatkowy dokument - dokument informacyjny, zgodny w swojej treści z załącznikiem nr 1 do Regulaminu ASO. Dokument ten wraz ze stosownym oświadczeniem autoryzowanego doradcy o jego kompletności przedkładany jest GPW wraz z wnioskiem o wprowadzenie akcji do obrotu. Stosunkowo prosta procedura przeprowadzenia oferty prywatnej sprawia, że emitenci decydujący się na jej przeprowadzenie i późniejszy debiut na rynku NewConnect moga uzyskać status spółki publicznej w okresie od 3 do 4 miesięcy ${ }^{21}$. Przy czym należy zaznaczyć, że nie powinno się stwarzać sztywnych ram czasowych przebiegu procedury upublicznienia, gdyż może ona ulec zarówno wydłużeniu, jak i skróceniu w zależności od indywidualnego przypadku danego emitenta.

Pozostałe kryteria wprowadzeniowe wymagają od spółek zmierzających na rynek NewConnect przedstawienia zbadanego sprawozdania finansowego za ostatni rok obrotowy - przy czym należy wskazać, że w regulaminie ASO nie pojawia się sformułowanie świadczące, iż musi on być pełen. W efekcie na rynku NewConnect moga zadebiutować podmioty o krótszej niż rok historii działalności. Z bardziej istotnych kryteriów warto również wyróżnić kryterium minimalnej wartości kapitałów własnych. Tutaj organizator ASO postawił wymóg w wysokości $500000 \mathrm{zl}$, przy czym biorąc pod uwagę minimalna wartość kapitału zakładowego dla spółek akcyjnych na poziomie 100000 zł² oraz fakt, że do wymogu zaliczane są wpływy z niezarejestrowanej emisji akcji - wydaje się, że wymóg ten nie stanowi istotnej przeszkody dla potencjalnych emitentów. Stworzenie wspomnianego kryterium mogło mieć na celu wyeliminowanie potencjalnych emitentów, którzy na skutek wygenerowanych strat w przeszłości charakteryzuja się ujemną wartością wspomnianej pozycji sprawozdania finansowego.

\section{WERYFIKACJA WYBRANYCH ZAŁOŻEŃ ORGANIZATORA RYNKU NEWCONNECT}

Giełda Papierów Wartościowych w Warszawie SA, tworząc rynek NewConnect, wpisała w swoje założenia, że ma być on rynkiem dla małych i średnich innowacyjnych przedsiębiorstw, które dzięki pozyskanemu kapitałowi przyspieszą swój rozwój. Niniejsze badanie ma na celu weryfikację wskazanych założeń, biorąc pod uwagę wybrane cechy charakterystyczne emitentów w momencie ich debiutu w alternatywnym systemie obrotu. Badaniu nie podlegały dalsze zmiany w zakresie rozwoju emitentów, już po wprowadzeniu przez nich akcji do obrotu. Badanie w zakresie wielkości podmiotów debiutujących na rynku NewConnect przeprowadzone zostało na podstawie definicji małe-

${ }^{21}$ B. Mikołajczyk, A. Kurczewska, op. cit., s. 68.

${ }^{22}$ Art. 308 ustawy z 15 września 2000 r. - Kodeks spółek handlowych, Dz. U. 2000, Nr 94, poz. 1037 ze zm. (dalej jako: k.s.h.). 
go i średniego przedsiębiorstwa z rozporządzenia Komisji (WE) nr 800/2008 uznającego niektóre rodzaje pomocy za zgodne ze wspólnym rynkiem w zastosowaniu art. 87 i 88 Traktatu (Dz. Urz. UE L 214 z 9 sierpnia 2008, s. 3), które stosuje się w przypadku udzielania MŚP pomocy publicznej. Definicja MŚP ma zastosowanie do wszystkich polityk, programów i działań, jakie Komisja Europejska realizuje wobec małych i średnich przedsiębiorstw. W treści załącznika nr 1 do rozporządzenia Komisji (WE) 800/2008 w art. 1 wyodrębniono następujące kategorie przedsiębiorstw, które przedstawiono w tabeli 1.

\section{Tabela 1}

Kryteria podziału wielkości przedsiębiorstw

\begin{tabular}{|l|l|l|}
\hline \multicolumn{1}{|c|}{ Wielkość } & \multicolumn{1}{|c|}{$\begin{array}{c}\text { Kryterium } \\
\text { zatrudnienia }\end{array}$} & \multicolumn{1}{c|}{$\begin{array}{c}\text { Kryterium obrotu } \\
\text { lub kryterium sumy bilansowej }\end{array}$} \\
\hline $\begin{array}{l}\text { Średnie } \\
\text { przedsiębiorstwo }\end{array}$ & Mniej niż 250 osób & $\begin{array}{l}\text { Roczny obrót nie przekracza } 50 \text { mln EUR } \\
\text { Suma bilansowa nie przekracza } 43 \text { mln EUR }\end{array}$ \\
\hline $\begin{array}{l}\text { Małe } \\
\text { przedsiębiorstwo }\end{array}$ & Mniej niż 50 osób & $\begin{array}{l}\text { Roczny obrót nie przekracza } 10 \text { mln EUR } \\
\text { Suma bilansowa nie przekracza } 10 \text { mln EUR }\end{array}$ \\
\hline $\begin{array}{l}\text { Mikroprzedsiębior- } \\
\text { stwo }\end{array}$ & $\begin{array}{l}\text { Mniej niż } \\
10 \text { pracowników }\end{array}$ & $\begin{array}{l}\text { Roczny obrót nie przekracza 2 mln EUR } \\
\text { Suma bilansowa nie przekracza 2 mln EUR }\end{array}$ \\
\hline
\end{tabular}

Źródło: opracowanie własne na podstawie art. 1 załącznika nr 1 do rozporządzenia Komisji (WE) $800 / 2008$.

Przy czym należy wskazać, że klasyfikacja przedsiębiorstwa do jednej z kategorii następuje na warunkach koniunkcji, warunkiem koniecznym do zakwalifikowania do danej kategorii jest spełnienie jednocześnie warunku zatrudnienia oraz wysokości obrotu lub sumy bilansowej.

Zgodnie z powyższymi kryteriami podziału wielkości przedsiębiorstw przeanalizowano wszystkie dokumenty informacyjne spółek z rynku NewConnect, które zadebiutowały od momentu jego powstania 31 sierpnia 2007 do końca grudnia 2015 r. Tym samym analizą objętych zostało 541 emitentów, z czego informację o zatrudnieniu w odpowiednim publicznym dokumencie informacyjnym zawarły 523 podmioty. Wyniki badań w zakresie wielkości przedsiębiorstw przedstawia wykres $\mathrm{nr} 1$.

Z 523 emitentów 356 spełniło kryterium mikroprzedsiębiorstwa, 160 zakwalifikowało się do kategorii małego i średniego przedsiębiorstwa, natomiast 7 posiadało status dużego. Otrzymane wyniki badań pozwalają na pozytywna weryfikację hipotezy głównej badania mówiącej, że rynek NewConnect jest rynkiem zdominowanym przez mikro-, małe i średnie przedsiębiorstwa. O pozytywnej weryfikacji hipotezy głównej świadczy fakt, że w momencie debiutu na rynku NewConnect wskazana grupa podmiotów stanowiła 98,7\% wszystkich emitentów. Jednocześnie można wskazać, że rynek NewConnect okazał się rynkiem dla mikroprzedsiębiorstw, a nie jak zakładał organizator ASO rynkiem dla podmiotów małych i średnich. 


\section{Wykres 1}

Struktura wielkości przedsiębiorstw debiutujących na NewConnect w latach 2007-2015

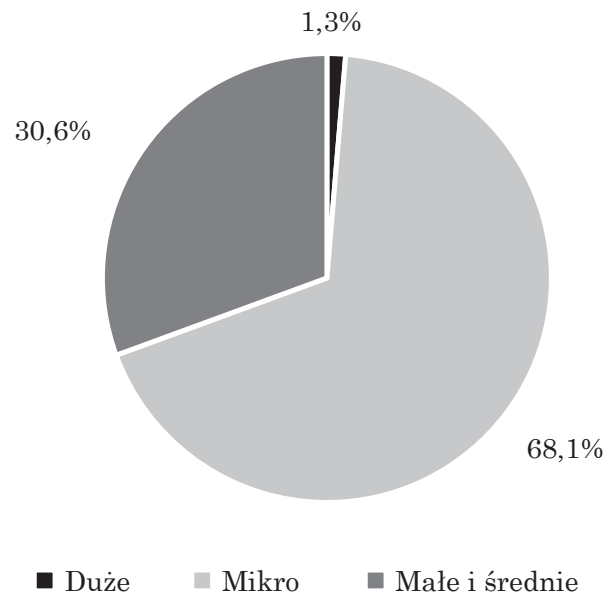

Źródło: opracowanie własne.

W zamyśle organizatora rynku NewConnect rynek ten miał być rynkiem dla innowacyjnych przedsiębiorstw, które opierają swoją działalność w głównej mierze na wartościach niematerialnych i prawnych. W celu weryfikacji wskazanego założenia przeprowadzono badanie w odniesieniu do struktury branżowej podmiotów, które zadebiutowały na rynku NewConnect w latach 2007-2015 oraz struktury aktywów wykazanych w ich bilansach. Do branż innowacyjnych zaliczone zostały: informatyka, technologie, e-handel, eco-energia, media oraz telekomunikacja ${ }^{23}$. Wyniki badania w zakresie struktury branżowej podmiotów przedstawia tabela 2. Jednocześnie należy zaznaczyć, że zaprezentowane podejście zawiera pewne uproszczenie - sama kwalifikacja spółki do sektora nie przesądza bowiem o jej innowacyjności, podobnie jak nie eliminuje innowacyjności w przypadku spółek kwalifikujących się do pozostałych branż notowanych na rynku.

Tabela 2

Struktura branżowa debiutantów na rynku NewConnect w latach 2007-2015

\begin{tabular}{|l|c|c|}
\hline \multicolumn{1}{|c|}{ Sektor } & Liczba spółek & Udział \\
\hline Handel & 82 & $15,16 \%$ \\
\hline Usługi inne & 68 & $12,57 \%$ \\
\hline Informatyka & 53 & $9,80 \%$ \\
\hline Usługi finansowe & 51 & $9,43 \%$ \\
\hline
\end{tabular}

${ }^{23}$ Zgodnie z informacjami z: http://newconnect.pl/index.php?page=o_rynku [dostęp: 25.02.2016]. 


\begin{tabular}{|l|c|c|}
\hline Budownictwo & 40 & $7,39 \%$ \\
\hline Media & 42 & $7,76 \%$ \\
\hline Technologie & 49 & $9,06 \%$ \\
\hline Inwestycje & 29 & $5,36 \%$ \\
\hline Ochrona zdrowia & 29 & $5,36 \%$ \\
\hline Wypoczynek & 20 & $3,70 \%$ \\
\hline Nieruchomości & 21 & $3,88 \%$ \\
\hline Telekomunikacja & 14 & $2,59 \%$ \\
\hline E-handel & 14 & $2,59 \%$ \\
\hline Eco-energia & 16 & $2,96 \%$ \\
\hline Recykling & 13 & $2,40 \%$ \\
\hline W tym innowacyjne & 188 & $34,75 \%$ \\
\hline
\end{tabular}

Źródło: opracowanie własne.

Z przeprowadzonych badań wynika, że najliczniejszą reprezentację wśród debiutujących spółek miały te z sektora handlu. Łączny udział przedsiębiorstw kwalifikujących się do sektorów uznanych za innowacyjne wyniósł 34,75\%.

Badanie w zakresie prowadzenia przez spółki z NewConnect działalności w oparciu o aktywa niematerialne i prawne przebiegło na dwa sposoby. W pierwszym najpierw wyłoniono grupę spółek, u której w strukturze aktywów przeważał majątek trwały, a następnie wyznaczono średni udział wartości niematerialnych i prawnych w sumie aktywów trwałych. Drugi sposób polegał natomiast na przyrównaniu wartości przypisanej aktywom niematerialnym i prawnym do sumy bilansowej i wyłonieniu spółek o ponad 50-procentowym udziale wskazanej pozycji w sumie aktywów ogółem. Wyniki przeprowadzonych badań przedstawiono w tabeli 3 .

Tabela 3

Wartości niematerialne i prawne w bilansach spółek debiutujących na NewConnect w latach 2007-2015

\begin{tabular}{|l|c|c|}
\hline \multicolumn{1}{|c|}{ Badany obszar } & Liczba spółek & Udział \\
\hline $\begin{array}{l}\text { Liczba spółek o majątku trwałym przewyższającym } \\
\text { majątek obrotowy }\end{array}$ & 181 & $33,33 \%$ \\
\hline $\begin{array}{l}\text { Średni udział WNiP w majątku trwałym dla grupy } \\
\text { emitentów o majątku trwałym większym od majątku } \\
\text { obrotowego }\end{array}$ & 181 & $25,76 \%$ \\
\hline Średni udział WNiP w sumie bilansowej & 541 & $9,72 \%$ \\
\hline Udział WNiP powyżej 50\% sumy bilansowej & 39 & $7,21 \%$ \\
\hline Udział WNiP powyżej 25\% sumy bilansowej & 83 & $15,34 \%$ \\
\hline Udział WNiP powyżej 10\% sumy bilansowej & 129 & $23,84 \%$ \\
\hline
\end{tabular}

Źródło: opracowanie własne. 
W ramach przeprowadzonych badań w zakresie struktur majątku spółek debiutujących na rynku NewConnect uzyskane wyniki wskazuja, że w przypadku 33,33\% (181) debiutantów majątek trwały przewyższał majątek obrotowy. W przypadku grupy debiutantów o dominującym udziale aktywów trwałych średni udział wartości niematerialnych w majątku trwałym osiagną wartość 25,76\%. Jednocześnie średni udział analizowanej pozycji w sumach bilansowych debiutantów rynku NewConnect w latach 2007-2015 wynosił $9,72 \%$. Wartości niematerialne i prawne miały dominujaccy udział w aktywach ogółem jedynie w przypadku 39 emitentów, co odpowiadało za 7,21\% wszystkich debiutantów ogółem. Zidentyfikowane zjawisko może wynikać z faktu, że organizator ASO w latach 2007-2015 nie zawarł w kryteriach wprowadzenia do obrotu wymogu przejawiania innowacyjności przez podmioty ubiegające się o wprowadzenie na rynek NewConnect. Tym samym analizowane założenie nie znalazło swojego odzwierciedlenia w obowiązujących regulacjach.

Uzyskane wyniki pozwalają na pozytywną weryfikację hipotezy czastkowej mówiącej, iż rynek NewConnect jest rynkiem nie tylko dla spółek kwalifikowanych do innowacyjnych branż. Zarówno zaprezentowane wyniki badania w zakresie struktury branżowej podmiotów, które zadebiutowały na rynku NewConnect, jak i uzyskane wyniki analizy struktury bilansów pod kątem istotności pozycji wartości niematerialnych i prawnych potwierdzają postawioną hipotezę. Tym samym założenie organizatora NewConnect polegające na dedykowaniu rynku innowacyjnym przedsiębiorstwom, opierającym swoja działalność na wartościach niematerialnych i prawnych nie zostało do końca spełnione. O ile bowiem takie podmioty zadebiutowały na rynku, o tyle nie stanowią one większości podmiotów, które zdecydowały się na upublicznienie.

\section{PODSUMOWANIE}

Przeprowadzone badania pozwoliły na pełną realizację zakładanego celu artykułu. Wyniki potwierdzają hipotezę główną mówiącą o tym, że rynek NewConnect jest rynkiem dla mikro-, małych i średnich przedsiębiorstw. Hipoteza ta została potwierdzona uzyskanymi wynikami badań, które świadcza o tym, iż 98,7\% emitentów w momencie debiutu kwalifikowało się do grupy mikro-, małych i średnich przedsiębiorstw. Pozytywnie zweryfikowana została także hipoteza czasstkowa. Wykazała ona, że rynek NewConnect jest rynkiem nie tylko dla innowacyjnych przedsiębiorstw, które opierają swoją działalność na wartościach niematerialnych i prawnych. Uzyskane wyniki wykazały, że spółki zaliczane do sektorów innowacyjnych odpowiadały za 34,75\% debiutantów na rynku NewConnect oraz że tylko w przypadku 7,21\% spółek wartości niematerialne i prawne stanowiły ponad 50\% ich sumy bilansowej. Wyniki badania pozwalają stwierdzić, iż rynek NewConnect w latach 2007-2015 tylko częściowo rozwijał się zgodnie z założeniami jego organizatora w zakresie ukierunkowania na małe i średnie innowacyjne przedsiębiorstwa - większa grupe od małych i średnich przedsiębiorstw stanowiły przedsiębiorstwa mikro, natomiast przedsiębiorstwa zaliczane do sektorów inne niż innowacyjne dominowały swoją liczebnością. 
Z uwagi na stosunkowo krótki okres funkcjonowania rynku NewConnect, który przypada na lata 2007-2015, istotne zmiany zachodzące w polskim otoczeniu gospodarczym - niepewność co do przyszłości kształtu rynku kapitałowego w Polsce, w tym możliwe negatywne skutki dalszej marginalizacji OFE - konieczne jest dalsze prowadzenie badań w obszarze rozwoju rynku NewConnect. Zasadne jest także przeprowadzenie bardziej szczegółowej analizy niż zaprezentowana, w tym w podziale na podokresy czy według cech debiutujących spółek (m.in. wielkość). Przeprowadzone badanie zweryfikowało dwa z sześciu założeń sformułowanych przez organizatora względem rynku NewConnect - stąd konieczne jest dalsze prowadzenie badań w tym zakresie, w szczególności w obszarze wartości ofert, kosztu pozyskania kapitału, stopnia rozwoju emitentów w momencie debiutu, a także ich późniejszych losów, $\mathrm{w}$ tym w kwestii przeniesienia na rynek regulowany.

mgr Piotr Zygmanowski

Uniwersytet Ekonomiczny w Poznaniu

piotr.zygmanowski@ue.poznan.pl

\section{NEWCONNECT MARKET DEVELOPMENT IN LIGHT OF ITS ORGANISER'S INITIAL ASSUMPTIONS}

\section{Sum mary}

The paper aims to answer a question whether the NewConnect market developed in 20072015 in line with the initial assumptions of its organiser regarding the type and the size of issuers. In the introduction the author has presented his main and secondary hypotheses. The first part of the article presents the theoretical basis of the impact of financial market development on economic growth, as well as the premises of NewConnect's foundation, its architecture and current listing criteria. The second part of the article contains the research result regarding the size of listed issuers and their type of business activity. The summary includes the author's conclusions with regards to the hypothesis, as well as identification of areas that require further analysis.

The study allowed full realisation of the main objective. The results confirm the primary hypothesis, proving that NewConnect is a market for micro, small and medium-sized companies. The verification of the secondary hypothesis proved that NewConnect is a market for all types of companies and not only for innovative companies that base their business on intangible assets. The research results indicate that the NewConnect market in 2007-2015 only partially developed in line with the initial assumptions of its organiser regarding the type and the size of issuers. 